\title{
Enzymatic transesterification of Jatropha oil
} Annapurna Kumari, Paramita Mahapatra, Vijay Kumar Garlapati and
Rintu Banerjee*

Address: Agricultural and Food Engineering Department, Indian Institute of Technology, Kharagpur, West Bengal 721302, India

Email: Annapurna Kumari - kumariannapurna92@gmail.com; Paramita Mahapatra - paramita.mahapatra@gmail.com; Vijay Kumar Garlapati - shanepati@agfe.iitkgp.ernet.in; Rintu Banerjee* - rb@agfe.iitkgp.ernet.in

* Corresponding author

Published: 14 January 2009

Biotechnology for Biofuels 2009, 2:I doi:10.1 186/1754-6834-2-1
Received: 17 July 2008

Accepted: 14 January 2009

This article is available from: http://www.biotechnologyforbiofuels.com/content/2/l/I

(c) 2009 Kumari et al; licensee BioMed Central Ltd.

This is an Open Access article distributed under the terms of the Creative Commons Attribution License (http://creativecommons.org/licenses/by/2.0), which permits unrestricted use, distribution, and reproduction in any medium, provided the original work is properly cited.

\begin{abstract}
Background: Transesterification of Jatropha oil was carried out in t-butanol solvent using immobilized lipase from Enterobacter aerogenes. The presence of t-butanol significantly reduced the negative effects caused by both methanol and glycerol. The effects of various reaction parameters on transesterification of Jatropha oil were studied.
\end{abstract}

Results: The maximum yield of biodiesel was $94 \%$ (of which $68 \%$ conversion was achieved with respect to methyl oleate) with an oil:methanol molar ratio of $1: 4,50 \mathrm{U}$ of immobilized lipase/g of oil, and a t-butanol:oil volume ratio of $0.8: \mathrm{I}$ at $55^{\circ} \mathrm{C}$ after $48 \mathrm{~h}$ of reaction time. There was negligible loss in lipase activity even after repeated use for seven cycles.

Conclusion: To the best of our knowledge this is the first report on biodiesel synthesis using immobilized $E$. aerogenes lipase.

\section{Background}

Biodiesel is a renewable fuel that can be synthesized from edible, non-edible and waste oils. Due to diminishing petroleum reserves, vegetable oils have attracted attention as a potential renewable source for the production of alternatives to petroleum-based diesel fuel. A number of processes have been developed for biodiesel production involving chemical or enzyme catalysis or supercritical alcohol treatment [1-4]. Enzymatic transesterification of triglycerides is a good alternative to chemical processes due to its eco-friendly, selective nature and low temperature requirements [5-9].

Many starting materials such as soybean oil $[10,11]$, sunflower oil [12,13], cotton seed oil [14], rapeseed oil [15], palm oil $[16,17]$ and restaurant kitchen wastes [18] have been evaluated for preparation of biodiesel by the enzy- matic route. In many countries, like India, where edible oils are not in surplus supply, there is a need to search for alternative starting materials, such as from non-edible oils. Oil of Jatropha curcas (Euphorbiaceae), a non-edible oil, has been chosen for the present investigation. The seeds and oil are toxic due to the presence of toxic phorbol esters. The oil content of Jatropha seed ranges from 30 to $50 \%$ by weight, whereas in kernel the oil content ranges from 45 to $60 \%$. The fatty acid composition of Jatropha oil consists of oleic acid 43.1\%, linoleic acid 34.3\%, stearic acid $6.9 \%$, palmitic acid $4.2 \%$ and other acids $1.4 \%$. Jatropha curcas is a low-growing tree, generally planted as a hedge for protecting crops from animals. It can be grown on barren land under harsh conditions and can be cultivated as a part of the strategy for reclaiming degraded lands [19]. Keeping all this in view, the Indian Government has announced a 'National Mission on 
Biodiesel' for Jatropha plantations in wasteland regions that is to be implemented on an area of 400,000 ha over the next five years [20].

There are many reports on biodiesel production using enzyme catalysis by free or immobilized lipases $[7,8,10,15,18,21-23]$. Immobilized lipase in particular is suitable for continuous biodiesel production because of the ease of its recovery from the reaction mixture. There are two major limitations of lipase-catalyzed biodiesel synthesis. One is higher cost (which can be reduced up to a certain extent by immobilization) and another is its inactivation by methanol and glycerol. It has been reported that as methanol is insoluble in vegetable oils, it inhibits the immobilized lipases and thereby decreases the catalytic activity of the transesterification reaction. Further, the hydrophilic by-product glycerol is also insoluble in the oil, so it is easily adsorbed onto the surface of the immobilized lipase leading to a negative effect on lipase activity and operational stability [24]. Use of several solvents such as $n$-hexane and petroleum ether in the reaction medium has been reported [25] but the problem persisted since the inhibition of lipases still occurred due to poor solubility of methanol and glycerol in the hydrophobic solvents [26]. There are some reports on enhanced biodiesel synthesis in presence of t-butanol as a solvent [27-29]. As both methanol and glycerol are soluble in tbutanol, the inhibitory effect of methanol and glycerol on lipase activity is reduced. Moreover, t-butanol is not a substrate for the lipases because it does not act on tertiary alcohols.

Biodiesel synthesis from Jatropha oil has been reported by Chromobacterium viscosum and Pseudomonas cepacia lipases. In both the cases the ethanolysis of Jatropha oil for biodiesel synthesis has been carried out [20-30]. In the present investigation, methanolysis of Jatropha oil was performed using immobilized lipase from Enterobacter aerogenes in the presence of $\mathrm{t}$-butanol as solvent.

\section{Materials and methods Chemicals}

Jatropha oil (HPLC grade) was kindly gifted by Professor P Das. Methanol was purchased from Qualigens. Methyl oleate was procured from Sigma. All other solvents and reagents were of AR grade and were obtained from Merck.

\section{Lipase production}

All experiments were carried out using lipase from E. aerogenes. The extracellular lipase production from E. aerogenes was carried out in $250 \mathrm{ml}$ Erlenmeyer flasks each containing $50 \mathrm{ml}$ of a medium composed of peptone $(0.5 \%)$, yeast extract $(0.3 \%), \mathrm{NaCl}(0.25 \%), \mathrm{MgSO} 4(0.05 \%)$ and coconut oil $(3.0 \%)$ at $\mathrm{pH}$ 7.0. Medium was sterilized and inoculated with $3.5 \mathrm{ml}(4 \times 108$ cells $/ \mathrm{ml})$ of inoculum fol- lowed by incubation for $60 \mathrm{~h}$ at $34^{\circ} \mathrm{C}$ with shaking at 200 $\mathrm{rpm}$. At the end of the incubation period, supernatant from the fermentation media was collected by centrifugation at $6987 \mathrm{~g}$ for $10 \mathrm{~min}$. Supernatant was treated with acetone $(1: 4 \mathrm{v} / \mathrm{v})$ for $1 \mathrm{~h}$ at $4{ }^{\circ} \mathrm{C}$ followed by centrifugation at $6987 \mathrm{~g}$ for $10 \mathrm{~min}$. The precipitate was dissolved in 50 $\mathrm{mM}$ phosphate buffer ( $\mathrm{pH}$ 5.0) and lyophilized for use as a crude lipase preparation for subsequent immobilization.

\section{Enzyme assay}

The lipase assay was performed spectrophotometrically using p-nitro phenyl palmitate as substrate [31]. p-nitro phenol was liberated from p-nitro phenyl palmitate by lipase mediated hydrolysis. One unit (U) of lipase was defined as the amount of enzyme that liberates one micromole of p-nitro phenol per minute under the assay conditions.

\section{Lipase immobilization}

Lipase from $E$. aerogenes was immobilized on silica activated with ethanolamine followed by cross-linking with glutaraldehyde, as described previously [32].

\section{Reaction setup for transesterification reaction}

Transesterification reaction was carried out at $30^{\circ} \mathrm{C}$ in screw-capped vials placed inside a reciprocal shaker. The initial reaction mixture consisted of oil:methanol molar ratio of 1:2, t-butanol:oil volume ratio of 0.2 , immobilized E. aerogene lipase $20 \mathrm{U}$ and $200 \mathrm{rpm}$ (unless otherwise stated), along with the respective controls (samples without enzyme). All the experiments were performed in triplicate and the results were reported as the mean \pm standard deviation.

\section{Sampling and analysis}

Samples were taken from the reaction mixture at specified time intervals. The samples were centrifuged at $6987 \mathrm{~g}$ for $10 \mathrm{~min}$ at $4{ }^{\circ} \mathrm{C}$ to remove the carrier containing the immobilized enzyme (thus negating the possibilities of additional reaction) followed by 100 -fold dilution of the initial sample with $n$-hexane. The stability tests were performed in t-butanol in each cycle (up to 20 cycles) and the supernatant and residual immobilized enzyme activities were tested for enzyme leaching for more than seven cycles; no leaching of enzyme either in the supernatant or in the residual immobilized enzyme was observed.

Synthesis of fatty acid methyl ester was analyzed by injecting the diluted aliquots of the reaction mixture in a gas chromatograph (Agilent 6820). The column temperature was kept at $150^{\circ} \mathrm{C}$ for $0.5 \mathrm{~min}$, raised to $250^{\circ} \mathrm{C}$ at $15^{\circ} \mathrm{C} /$ min and was maintained at this temperature for $6 \mathrm{~min}$. The temperatures of the injector and detector were set at 245 and $350^{\circ} \mathrm{C}$ respectively. The \% molar conversion of 
products was identified by comparing the peak areas of standard methyl esters at particular retention times. Quantification of the final products (fatty acid methyl esters) was done from the calibration curves of pure fatty acid methyl esters (methyl oleate, methyl linoleate, methyl stearate and methyl palmitate).

\section{Results and discussion Effect of substrate molar ratio}

The optimum level of methanol concentration for the maximum synthesis of biodiesel was investigated. The transesterification reaction was carried out at $30^{\circ} \mathrm{C}$, using $20 \mathrm{U}$ of immobilized lipase with different molar ratios as shown in Figure 1. Alcohol in excess of the stoichiometric molar ratio of 1:3 (oil:methanol) was used to ensure higher biodiesel yield. As was expected, an increase in the number of moles of alcohol with respect to the triglycerides resulted in an increase in the production of esters. Ultimately, the formation of esters reached a maximum level with 1:4 Jatropha oil:methanol molar ratio, and a further increase in alcohol concentration resulted in a decrease in the formation of esters. The maximum biodiesel synthesis rates from rapeseed oil and cotton seed oil were reported at 1:3.6 and 1:4 oil:methanol ratio, respectively $[27,29]$.

\section{Effect of agitation speed}

In case of immobilized catalyst, the reactants need to diffuse from the bulk liquid to the external surface of the particle and from there into the interior pores of the catalyst. External mass transfer limitations can be minimized by carrying out the reaction at an optimum speed of agitation [33]. The effect of speed of agitation on conversion was studied in the range of 100 to $250 \mathrm{rpm}$ (Figure 2). It was found that the percentage conversion increased with

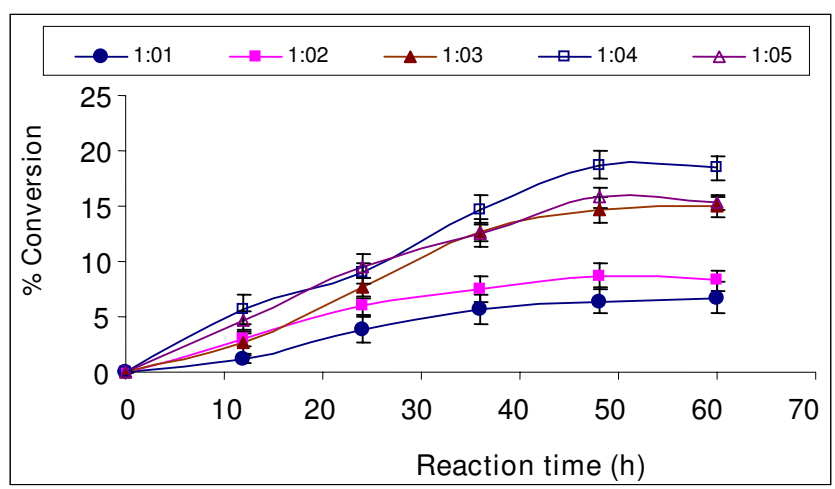

Figure I

Effect of substrate molar ratio on biodiesel synthesis. Reaction conditions: $20 \mathrm{U}$ of immobilized $E$. aerogenes lipase, t-butanol:oil volume ratio of $0.2,30^{\circ} \mathrm{C}$ and $200 \mathrm{rpm}$. Data are represented as mean \pm standard deviation of triplicate observation.

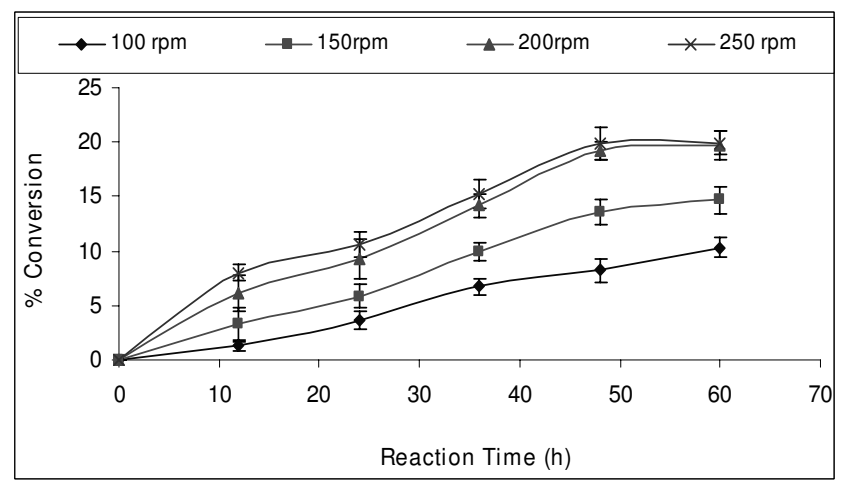

Figure 2

Effect of agitation speed on biodiesel synthesis. Reaction conditions: 1:4 oil to methanol molar ratio, $20 \mathrm{U}$ of immobilized $E$. aerogenes lipase, t-butanol:oil volume ratio of 0.2 and $30^{\circ} \mathrm{C}$. Data are represented as mean \pm standard deviation of triplicate observation.

speeds from 100 to $200 \mathrm{rpm}$. However, no further increase in percentage conversion was observed at 250 rpm, which may be due to shearing of the enzyme molecules. Thus, the optimum speed for transesterification reaction was found to be $200 \mathrm{rpm}$.

\section{Effect of t-butanol quantity}

Biodiesel synthesis was greatly influenced by addition of t-butanol to the reaction mixture. In the absence of t-butanol there was no biodiesel synthesis, which may be due to inhibition of lipase by methanol. Generally transesterification of Jatropha oil was carried out using ethanol [2030]. Immersion of lipases in t-butanol and other alcohols with a carbon number of more than three was claimed as a pretreatment method to increase lipase activity in synthesis of methyl esters [34,35]. Moreover, the negative effects caused by methanol and glycerol can be eliminated by the ability of t-butanol to dissolve both methanol and glycerol $[23,26]$. Various quantities of t-butanol were added to the reaction mixture in order to observe the effect of t-butanol concentration on the transesterification reaction. The percentage biodiesel conversion was found to increase greatly with increase in t-butanol:oil volume ratio with a maximum conversion at a t-butanol:oil volume ratio of 0.8 (Figure 3). On further increase in t-butanol concentration no increment in biodiesel synthesis was observed.

\section{Effect of reaction temperature}

An increase in temperature speeds up enzyme-mediated reactions just like any other non-enzyme catalyzed reactions. However, enzymes are proteins and are dependent on their specific structure for their activity, and may become denatured when heated beyond an optimum temperature. Experiments were performed over the tem- 


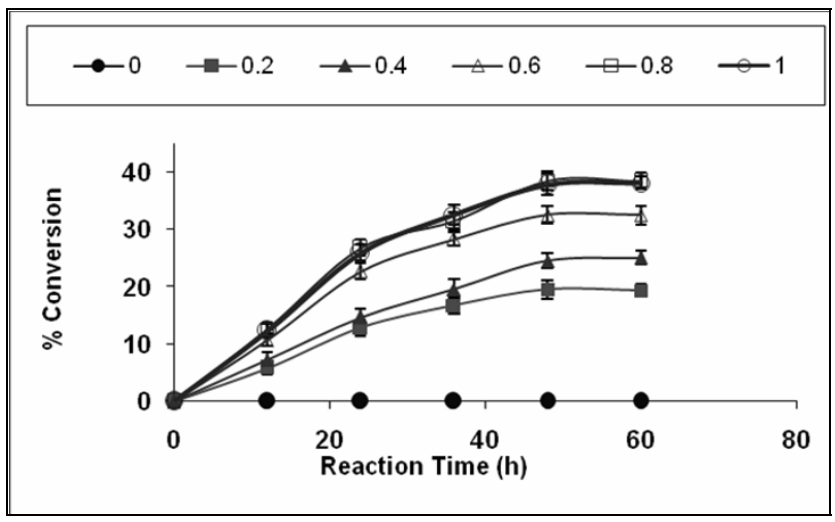

Figure 3

Effect of $t$-butanol various $t$-butanol/oil volume ratio on biodiesel synthesis. Reaction conditions: $1: 4$ oil to methanol molar ratio, $20 U$ of immobilized $E$. aerogenes lipase $30^{\circ} \mathrm{C}$ and $200 \mathrm{rpm}$. Data are represented as mean \pm standard deviation of triplicate observation.

perature range of 30 to $55^{\circ} \mathrm{C}$ to examine the effect of temperature on the immobilized lipase for the synthesis of biodiesel at 1:4 Jatropha oil:methanol molar ratio with 20 $\mathrm{U}$ of immobilized lipase (Figure 4). Transesterification activity of lipase was found to continuously increase with increase in temperature, with a maximum conversion at $55^{\circ} \mathrm{C}$. Royon et al also carried out the transesterification of cotton seed oil in t-butanol at $50^{\circ} \mathrm{C}$ [29]. The activation energy was calculated from the graph shown in Figure 5 where slope was equal to $-E / R$. In the present reaction, the apparent activation energy was $14.73 \mathrm{~kJ} / \mathrm{mol}$. Royon et al reported an activation energy of $19.2 \mathrm{~kJ} / \mathrm{mol}$ for the transesterification of cotton seed oil [29].

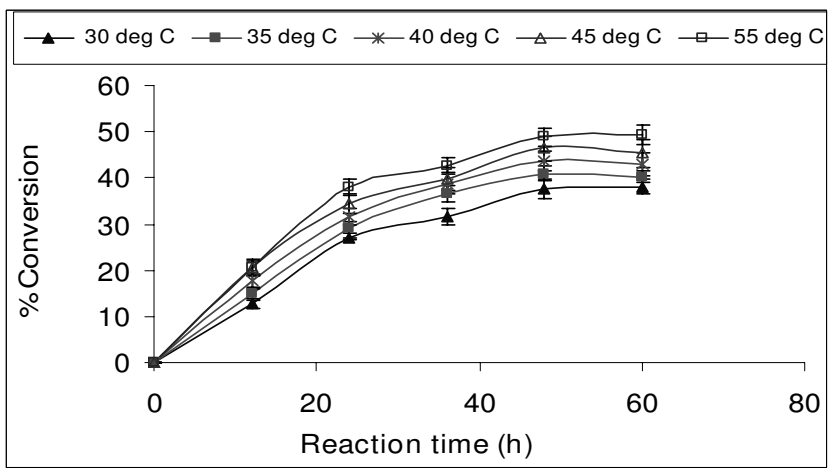

Figure 4

Effect of temperature on biodiesel synthesis. Reaction conditions: I: 4 oil to methanol molar ratio, $20 \mathrm{U}$ of immobilized $E$. aerogenes lipase, t-butanol:oil volume ratio of 0.8 and $200 \mathrm{rpm}$. Data are represented as mean \pm standard deviation of triplicate observation.

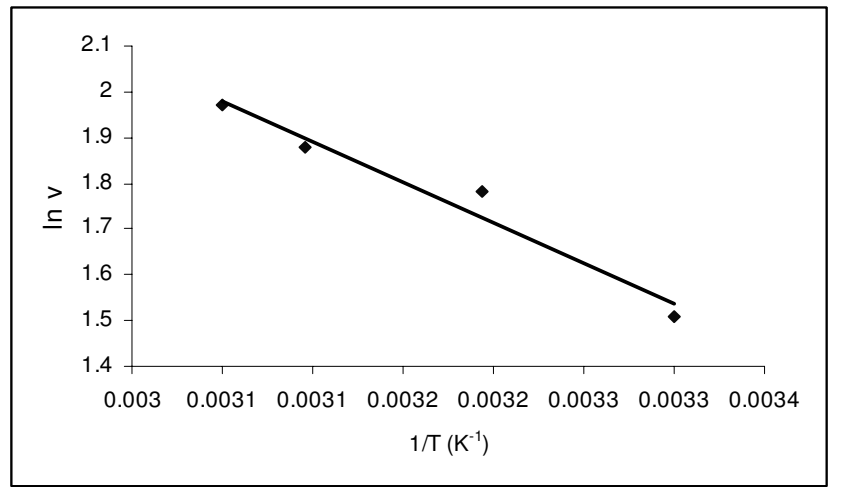

Figure 5

Arrhenius plot of activation energy for biodiesel synthesis by lipase $E$. aerogenes.

\section{Effect of additional water content}

A common thread in all studies of enzymes in organic media is that the amount of water associated with the enzyme is a key determinant of the properties (for example, activity, stability and specificity) that the enzyme exhibits. The effect of initial water concentration on the transesterification reaction was investigated through the addition of water ranging from 5 to $20 \%(\mathrm{v} / \mathrm{v})$ of the total amount of reaction mixture (Figure 6). It was observed that percentage conversion was a maximum when there was no additional water in the reaction mixture. Although water is necessary for acquisition and maintenance of enzymes' catalytically active conformation in essentially anhydrous organic solvents, water is also involved in many enzyme inactivation processes [36]. As long as a minimal amount of water is associated with the enzyme, its activity in the organic media is retained. However, too

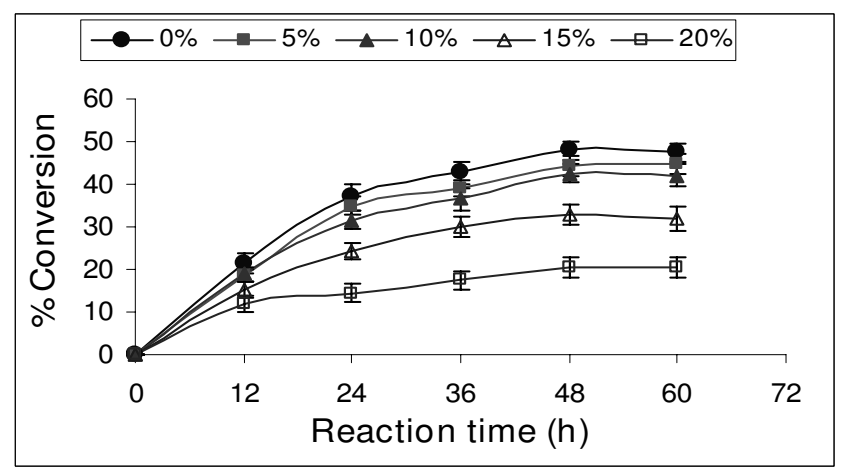

\section{Figure 6}

Effect of water content on biodiesel synthesis. Reaction conditions: I:4 oil to methanol molar ratio, $20 \mathrm{U}$ of immobilized $E$. aerogenes lipase, t-butanol:oil volume ratio of $0.8,55^{\circ} \mathrm{C}$ and $200 \mathrm{rpm}$. Data are represented as mean \pm standard deviation of triplicate observation. 
much water facilitates enzyme aggregation, which leads to a decrease in enzyme activity. A similar effect was observed in the methanolysis reaction of soybean oil using lipase from Mucor miehei [15] and in the transesterification reaction of triolein with propanol by $\mathrm{Pseu}$ domonas fluorescens lipase [6].

\section{Effect of enzyme concentration}

The effect of enzyme concentration on the transesterification reaction was also investigated. The enzyme concentration was varied from 20 to $60 \mathrm{U}$ at 1:4 Jatropha oil:methanol molar ratio and at $55^{\circ} \mathrm{C}$ as shown in Figure 7. The synthesis of fatty acid methyl ester initially increased with increase in the enzyme amount with maximum conversion of $68 \%$ at $50 \mathrm{U}$ of immobilized E. aerogenes lipase, whereas upon further increase in the enzyme amount no significant increase in biodiesel synthesis was observed. A previous study has demonstrated that the yield of 1-butyl oleate increased when the amount of Rhizopus oryzae lipase was increased from 30 to $60 \mathrm{U}$ and remained almost constant with increase in lipase amount beyond $60 \mathrm{U}$ [25]. Similar results were reported for the methanolysis of rice bran oil catalysed by Cryptococcus spp. S-2 lipase [7]. This may be due to the fact that in the presence of a high amount of lipase, the active site cannot be exposed to the substrates and many molecules of the enzyme aggregate together. Agglomeration using immobilized lipases in a solvent-free system has been previously reported $[37,38]$.

\section{Reusability of lipase}

The repeated use of immobilized enzyme may help to bring down the product cost and make the enzymatic process economically viable [39]. Operational stability or reusability is of importance in determining immobilized

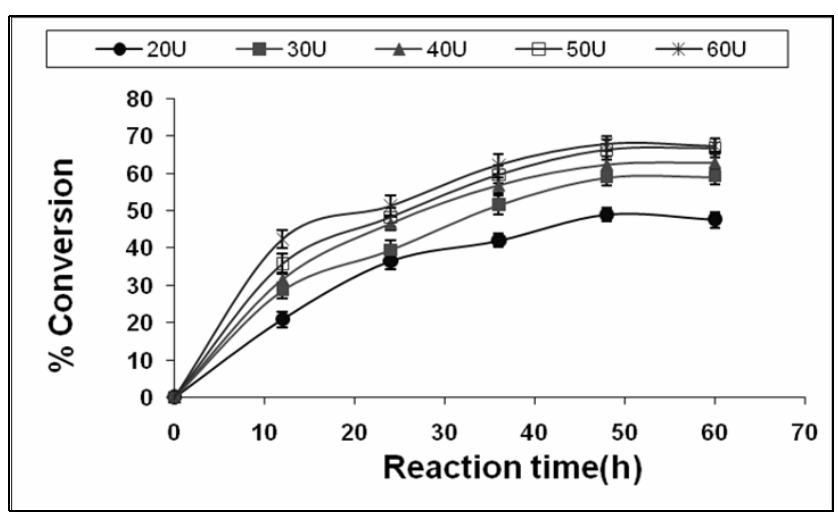

Figure 7

Effect of enzyme amount on biodiesel synthesis. Reaction conditions: $1: 4$ oil to methanol molar ratio, t-butanol:oil volume ratio of $0.8,55^{\circ} \mathrm{C}$ and $200 \mathrm{rpm}$. Data are represented as mean \pm standard deviation of triplicate observation. enzyme efficiency. However, it was observed that reaction behaviour changes when an immobilized enzyme is used repeatedly. The immobilized lipase was filtered at the end of the reaction, washed with t-butanol and again introduced with fresh reactants in order to study its operational stability in each cycle. No apparent loss in the ability of biodiesel synthesis of immobilized lipase was observed even after seven cycles of use in t-butanol system (Figure 8 ). This may be due to the presence of t-butanol in the reaction medium drastically reducing glycerol adsorbed on immobilized lipase, leading to enhanced lipase stability even after several uses. However, the relative activity gradually decreased to $50 \%$ after 20 cycles, which might be due to loss of enzyme during filtration and drying (since no make-up quantities of enzyme were added), prolonged interaction of the organic solvent (t-butanol) with the immobilized enzyme resulting in the denaturation of the enzyme, and the production of substantial quantities of co-product water after each cycle [40]. From this study, immobilization of lipase onto a porous support through physical adsorption has been proven to be a useful technique for improving enzyme activity through direct interaction with the lipase besides protecting it from direct inactivation by reactant and product, which is in accordance with the previous results [41].

\section{Fuel properties of Jatropha oil methyl esters}

The fuel properties of Jatropha oil methyl ester in comparison with that of biodiesel standards has been shown in Table 1 . The present results showed that the transesterification process improved the fuel properties of the oil with respect to viscosity, flash point and pour point. The com-

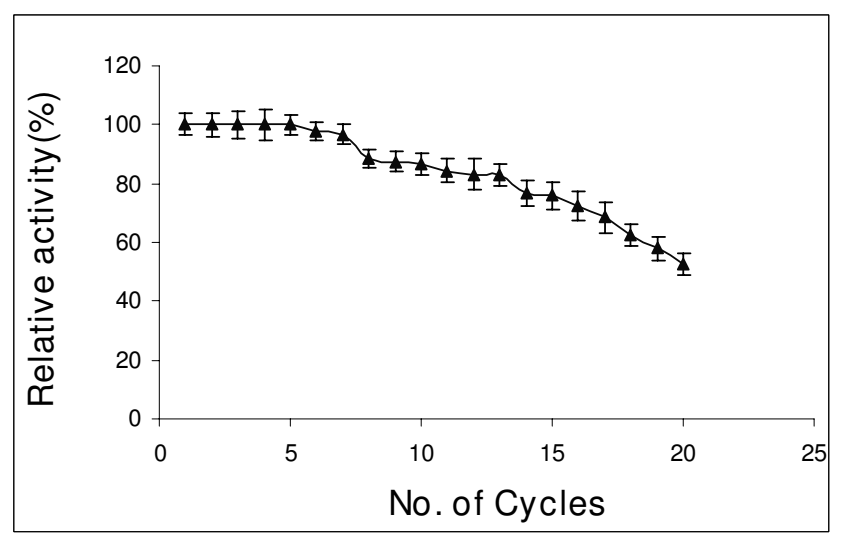

Figure 8

Operational stability of $E$. aerogenes lipase for biodiesel synthesis. Reaction conditions: I:4 oil to methanol molar ratio, $50 \mathrm{U}$ of immobilized $E$. aerogenes lipase, $\mathrm{t}$-butanol:oil volume ratio of $0.8,55^{\circ} \mathrm{C}$ and $200 \mathrm{rpm}$. Data are represented as mean \pm standard deviation of triplicate observation. 
Table I: Fuel properties of methyl esters of Jatropha oil

\begin{tabular}{lllll}
\hline Property & Jatropha oil & Jatropha biodiesel & Biodiesel standard ASTM 675I-02 & Biodiesel standard EN I42 I4 \\
\hline Viscosity $\left(\mathrm{mm}^{2} / \mathrm{s}\right)$ & 24.5 & 8.2 & 1.9 to 6.0 & 3.5 to 5.0 \\
Flash point $\left({ }^{\circ} \mathrm{C}\right)$ & 210 & 8.2 & $>130$ & $>120$ \\
Pour point $\left({ }^{\circ} \mathrm{C}\right)$ & 10 & 5 & -15 to 10 & - \\
Calorific value $(\mathrm{MJ} / \mathrm{kg})$ & 36.2 & 36.5 & 33 to 40 & - \\
\hline
\end{tabular}

parison of these properties with diesel showed that the methyl ester has relatively closer fuel property values to that of biodiesel standard (than that of the oil). There is a substantial decrease in the viscosity compared with that of Jatropha oil, although the viscosity of the Jatropha biodiesel was slightly higher than the standard range of viscosity of biodiesel. Moreover, generally biodiesel blended with diesel is used as fuel, so no hardware modifications would be required for handling this fuel (diesel blends) in the existing engine. The flash point of Jatropha oil is lowered by transesterification, but it is still higher than that of diesel. So a small percentage addition of biodiesel with diesel increases the flash point of diesel. Hence, it is safer to store biodiesel-diesel blends as compared with diesel alone. The tested properties of methyl esters of Jatropha oil were found to be in reasonable agreement with ASTM 6751 and EN 14214.

\section{Conclusion}

The present study shows that the efficient methanolysis of Jatropha oil is possible by lipase catalysis in presence of tbutanol as solvent. The present work is a comprehensive study on the reaction parameters influencing the enzymatic synthesis of biodiesel. Immobilized $E$. aerogenes lipase was employed to catalyze the transesterification reaction. The amount of enzyme and temperature were found to have an immense effect on biodiesel synthesis. The conversion increased with increasing temperature up to $55^{\circ} \mathrm{C}$, which was near the boiling point of the reaction mixture. About $94 \%$ yield of biodiesel was obtained (of which $68 \%$ conversion was achieved with respect to methyl oleate) using $50 \mathrm{U}$ of immobilized E. aerogenes lipase with $1: 4$ oil to methanol molar ratio at $55^{\circ} \mathrm{C}$ for 48 $\mathrm{h}$. The high operational stability of immobilized lipase also indicates the efficiency of the process. From the present work, it has been demonstrated that methanolysis of Jatropha oil could be effectively carried out in this novel system with a good operational stability of the lipases. However, further research and development on additional fuel property measures, long-term run and wear analysis of biodiesel-fuelled engines is necessary.

\section{Competing interests}

The authors declare that they have no competing interests.

\section{Authors' contributions}

AK carried out the lipase production and transesterification study of jatropha oil. PM and VKG helped in the immobilization and fuel properties determination tasks. $\mathrm{RB}$ conceived of the study, and participated in its design and coordination. All authors read and approved the final manuscript.

\section{Acknowledgements}

The authors gratefully acknowledge CSIR, Govt of India and Department of Biotechnology, India for providing research fellowship to Annapurna

Kumari and Paramita Mahapatra respectively.

\section{References}

I. Fukuda $\mathrm{H}$, Kondo $\mathrm{A}$, Noda $\mathrm{H}$ : Biodiesel fuel production by transesterification of oils. J Biosci Bioeng 200I, 92:405-4I6.

2. Zhang Y, Dube MA, McLean DD, Kates M: Biodiesel production from waste cooking oil. I. Process design and technological assessment. Bioresour Technol 2003, 89:1-16.

3. Kusdiana D, Saka S: Effects of water on biodiesel fuel production by supercritical methanol treatment. Bioresour Technol 2004, 91 : 289-295.

4. Warabi $Y$, Kusdiana $D$, Saka S: Reactivity of triglycerides and fatty acids of rapeseed oil in supercritical alcohols. Bioresour Technol 2004, 9 I:283-287.

5. Kaieda M, Samukawa T, Matsumoto T, Ban K, Kondo A, Shimada Y, Noda $\mathrm{H}$, Nomoto F, Ohtsuka K, Izumoto E, Fukuda H: Biodiesel fuel production from plant oil catalyzed by Rhizopus oryzae lipase in a water-containing system without an organic solvent. J Biosci Bioeng 1999, 88:627-63I.

6. Iso M, Chen B, Eguchi M, Kudo T, Shrestha S: Production of biodiesel fuel from triglycerides and alcohol using immobilized lipase. J Mol Catal Part B: Enzym 200I, 16:53-58.

7. Kamini NR, lefuji H: Lipase catalyzed methanolysis of vegetable oils in aqueous medium by Cryptococcus spp. S-2. Process Biochem 200I, 37:405-4I0.

8. Du W, Xu YY, Zeng J, Liu DH: Novozym 435-catalysed transesterification of crude soya bean oils for biodiesel production in a solvent-free medium. Biotechnol Appl Biochem 2004, 40:187-190

9. Du W, Xu YY, Liu DH, Li ZB: Study on acyl migration in immobilized lipozyme TL-catalyzed transesterification of soybean oil for biodiesel production. J Mol Catal B: Enzym 2005, 37:68-7I.

10. Schwab AW, Dykstra GJ, Selke E, Sorenson SC, Pryde EH: Diesel fuel from thermal decomposition of soybean oil. J Am Oil Chem Soc 1988, 65:1781-1786.

II. Samukawa T, Kaieda M, Matsumoto T, Ban K, Kondo A, Shimada Y, Noda H, Fukuda H: Pretreatment of immobilized Candida antarctica lipase for biodiesel fuel production from plant oil. J Biosci Bioeng 2000, 90: I80-183.

12. Bélafi Bakó K, Kovács F, Gubicza L, Hancsók J: Enzymatic biodiesel production from sunflower oil by Candida antarctica lipase in a solvent-free system. Biocatal Biotransform 2002, 20:437-439.

13. Dossat V, Combes D, Marty A: Lipase-catalyzed transesterification of high oleic sunflower oil. Enzyme Microbiol Technol 2002, 30:90-94.

14. Öznur K, Tüter M, Aksoy HA: Immobilized Candida antarctica lipase-catalyzed alcoholysis of cottonseed oil in a solventfree medium. Bioresour Technol 2002, 83: I 25-129. 
15. Nelson LA, Foglia TA, Marmer WN: Lipase catalyzed production of biodiesel. J Am Oil Chem Soc 1996, 73: I I9I-I 195.

16. Abigor RD, Uadia PO, Foglia TA, Hass MJ, Jones KC, Okpefa E, Obibuzor JU, Bafor ME: Lipase-catalyzed production of biodiesel fuel from some Nigerian lauric oils. Biochem Soc Trans 2000, 28:979-98I.

17. Crabbe E, Nolasco-Hipolito C, Kobayashi G, Sonomoto K, Ishizaki A: Biodiesel production from crude palm oil and evaluation of butanol extraction and fuel properties. Process Biochem 200I, 37:65-7I.

18. Hsu AF, Jones K, Foglia TA, Marmer WN: Immobilized lipase-catalyzed production of alkyl esters of restaurant grease as biodiesel. Biotechnol Appl Biochem 2002, 36:181-186.

19. Francis G, Edinger R, Becker KA: Concept for simultaneous wasteland reclamation, fuel production, and socio-economic development in degraded areas in India: need, potential and perspective of Jatropha plantation. Nat Resour Forum 2005, 29:12-24.

20. Shah S, Gupta MN: Lipase catalyzed preparation of biodiesel from Jatropha oil in a solvent-free system. Process Biochem 2007, 42:409-4I4.

21. Shimada $Y$, Watanabe $Y$, Samukawa T, Sugihara A, Noda $H$, Fukuda $H$, Tominaga $Y$ : Conversion of vegetable oil to biodiesel using immobilized Candida antarctica lipase. J Am Oil Chem Soc 1999, 76:789-793.

22. Kaieda M, Samukawa T, Kondo A, Fukuda H: Effect of methanol and water contents on production of biodiesel fuel from plant oil catalyzed by various lipases in a solvent-free system. J Biosci Bioeng 200I, 91:12-15.

23. Watanabe $Y$, Shimada $Y$, Sugihara $A$, Noda $H$, Fukuda $H$, Tominaga $Y$ : Continuous production of biodiesel fuel from vegetable oil using immobilized Candida antarctica lipase. J Am Oil Chem Soc 2000, 77:355-360.

24. Shimada $Y$, Watanabe $Y$, Sugihara A, Tominaga $Y$ : Enzymatic alcoholysis for biodiesel fuel production and application of the reaction to oil processing. J Mol Catal B: Enzym 2002, I 7: I 33- 142.

25. Ghamguia H, Karra Châabouni M, Gargouri Y: I-Butyl oleate synthesis by immobilized lipase from Rhizopus oryzae: a comparative study between $n$-hexane and solvent-free system. Enzyme Microb Technol 2004, 35:355-363.

26. Dossat $V$, Combes $D$, Marty $A$ : Continuous enzymatic transesterification of high oleic sunflower oil in a packed bed reactor: influence of the glycerol production. Enzyme Microb Technol 1999, 25:194-200.

27. Li L, Du W, Liu D, Wang L, Li Z: Lipase-catalyzed transesterification of rapeseed oils for biodiesel production with a novel organic solvent as the reaction medium. J Mol Catal Part B: Enzym 2006, 43:58-62.

28. Wang L, Du W, Liu D, Li L, Dai N: Lipase-catalyzed biodiesel production from soybean oil deodorizer distillate with absorbent present in tert-butanol system. I Mol Catal Part B Enzym 2006, 43:29-32.

29. Royon D, Daz M, Ellenrieder G, Locatelli S: Enzymatic production of biodiesel from cotton seed oil using t-butanol as a solvent. Bioresour Technol 2007, 98:648-653.

30. Shah S, Sharma S, Gupta MN: Biodiesel preparation by lipasecatalyzed transesterification of Jatropha oil. Energy Fuels 2004, 18:154-159.

31. Kordel M, Hofmann B, Schomburg D, Schmid RD: Extracellular lipase of Pseudomonas sp. strain ATCC-2 purification, characterization, crystallization, and preliminary $X$-ray diffraction data. J Bacteriol I808, I73:4836-484I.

32. Kumari A, Mahapatra P, Kumar GV, Banerjee R: Comparative study of thermostabilty and ester synthesis ability of free and immobilized lipases on cross-linked silica gel. Bioprocess Biosyst Eng 2007, 31:291-298.

33. Yadav GD, Trivedi AH: Kinetic modeling of immobilized-lipase catalyzed transesterification of $n$-octanol with vinyl acetate in non-aqueous media. Enzyme Microbiol Technol 2003, 32:783-789.

34. Wu WT, Chen JW: Method of preparing lower alkyl fatty acids esters and in particular biodiesel. US Patent no. 6,398,707 2002

35. Chen JW, Wu WT: Regeneration of immobilized Candida antarctica lipase for transesterification. I Biosci Bioeng 2003, 95:466-469.
36. Volkin DB, Staubli A, Langer R, Klibanov AM: Enzyme thermo inactivation in anhydrous organic solvents. Biotechnol Bioeng 1991, 37:843-853.

37. Liou YC, Marangoni AG, Yada RY: Aggregation behavior of Candida rugosa lipase. Food Res Intern 1998, 3 I:243-248.

38. Foresti ML, Ferreira ML: Solvent-free ethyl oleate synthesis mediated by lipase from Candida antarctica B adsorbed on polypropylene powder. Catal Today 2005, 107-108:23-30.

39. Ye P, Xu ZK, Wu J, Innocent C, Seta P: Nanofibrous poly (acrylonitrile-co-maleic acid) membranes functionalized with gelatin and chitosan for lipase immobilization. Biomaterials 2006, 27:4169-4I76.

40. Dave R, Madamwar D: Esterification in organic solvents by lipase immobilized in polymer of PVA-alginate-boric acid. Process Biochem 2006, 41:95I-955.

4I. Persson M, Wehtje E, Adlercreutz P: Factors governing the activity of lyophilized and immobilized lipase preparation in organic solvents. Chembiochem 2002, 3:566-57I.
Publish with Biomed Central and every scientist can read your work free of charge

"BioMed Central will be the most significant development for disseminating the results of biomedical research in our lifetime. "

Sir Paul Nurse, Cancer Research UK

Your research papers will be:

- available free of charge to the entire biomedical community

- peer reviewed and published immediately upon acceptance

- cited in PubMed and archived on PubMed Central

- yours - you keep the copyright 